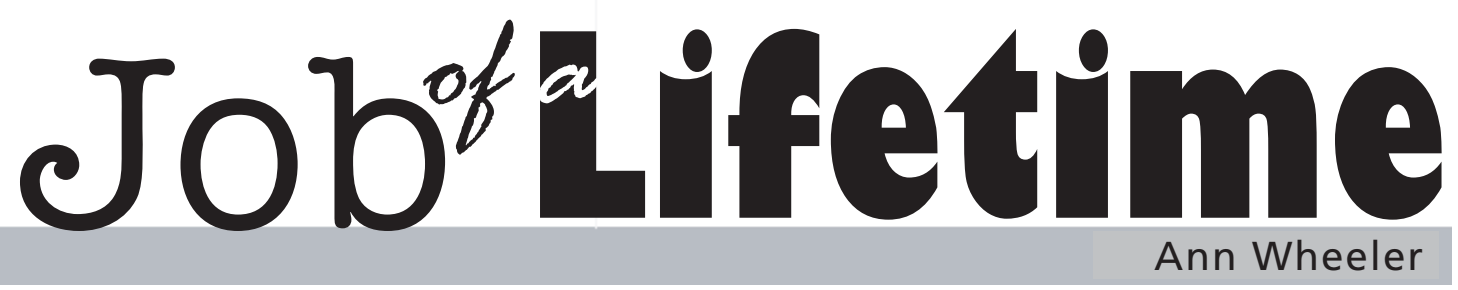

\title{
Giving back to those who serve: Greta Marlatt and the Naval Postgraduate School
}

$\mathbf{F}_{\text {ones }}$ or the past 13 years, Greta Marlatt has been doing what she loves as information services manager at the Naval Postgraduate School (NPS) in Monterey, California. NPS offers advanced degrees to military personnel in a range of academic subjects, all with a goal of improving military operations. Since 2002, NPS has also offered degrees to civilians through the Center for Homeland Defense and Security (CHDS). Marlatt answered my questions about her experiences as a military librarian at this job of a lifetime.

How did you rst get involved in libraries?

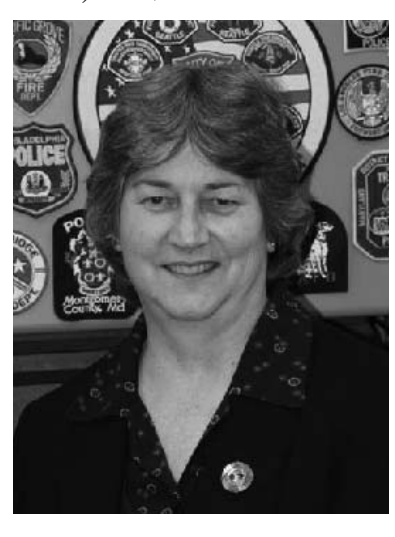

Greta Marlatt
At NPS you are subject specialist to a range of programs, including Information Warfare, Special Operations, and Homeland Defense and Security. What has been most challenging?

The homeland security program has been
I've always had an interest in libraries. I started working in one as an undergraduate at Arizona State [University] in a variety of positions and ended up in the Government Documents department. This was pre-Internet, and in many libraries government documents were not even cataloged. I'm inquisitive enough that I would thumb through them, and [I] paid attention to what was in them. It was like a whole new world of information that other librarians sometimes found scary.

The government produces statistics on just about anything, and has rules and regulations on just about everything. You have to be a subject specialist in a big world. I just found it very interesting. quite a challenge, and very interesting. After $9 / 11$, when the program was created, I didn't have a lot of background in emergency management, public health, criminal justice, immigration, and all of those issues that are part of homeland security. I've had to get smart pretty quickly to stay one step ahead of the students, many of whom are middle managers in fire departments, police departments, emergency management, and public health, etc.; these are people who are experts in their fields.

I read the article you coauthored, Libraries in the war on terrorism, which discusses NPS s CHDS Homeland Security Digital Library. How did that project get started?

When the school establishes the master's program in homeland security, the center's director felt that we needed a digital library to capture the emerging information. All of

Ann Wheeler is the librarian at the Maryland Department of Natural Resources. Have a story idea for Job of a Lifetime? E-mail Ann at awheeler@dnr.state.md.us 
the students in the program are professionals with full-time jobs, and their agencies aren't going to allow them to take 18 months off to go to school, so the program is largely a distance one. The Homeland Security Digital Library was developed to support those students as well as the defense and homeland security communities in general. We know that we have somewhere between 9,000 and 10,000 individual subscribers, but this does not include users who have access through IP or domain-level access. The digital library is not open to the public at-large, but we are trying to make it widely available to those who need it.

For example, we just signed an MOU [Memorandium of Understanding] with the Federal Depository Library Program, and through that we are making it available to any depository library. We're also trying to get to the firefighters, police, and emergency management people across the country. Currently, one of our biggest users is the Los Angeles Fire Department.

\section{What type of materi- als are in the Home- land Security Digital Library (HSDL)?}

The HSDL focuses on strategy, policy, and management documents. In addition to collecting digital materials of all kinds, including documents, maps, images and Webcasts, we've ended up digitizing a variety of older things, such as executive orders and public laws because they just aren't in digital form and they are important from a historical perspective. We want to make it as easy for the researcher as we can.

\section{What do you nd most rewarding about working at NPS?}

It's really my way of giving back. I chose not to join the military, but I very much appreciate what the military are willing to do, that they're out there serving and protecting us. In the homeland security program, it's the same thing. These are not people in a military uniform, but they might be in a firefighter's uniform, or a police uniform, or work in a hospital. They're also out there putting their lives on the line to save, serve, and protect us. I love the fact that I'm able to help them, in a behind-the-scenes way, do their job just a little bit better.

\section{Do you think there is misunderstand- ing in the library world about military librarianship?}

I don't know if I'd call it a misunderstanding [or] just a lack of understanding. Sometimes people think that because we're a military institution, we must only use military publications. Or if I tell them that I work with intelligence materials, they say, oh, you can't tell me about it because you'd have to shoot me. The reality is a lot of intelligence material is actually open source. Sometimes people think that working for the military means you support a particular political party. If I had to give a message out there, it would be that whatever you think of the military, whatever you think of the current President's policy, whoever that president might be, is unrelated to the fact that you're working in a library that's supporting a specific group of people. They just happen to wear a uniform.

\section{What would you say to someone consid-} ering a job in a military library?

I'm very passionate about what I do and I love what I do. I would love to see more people interested in working in the military community. We need more people, and we need some enthusiastic people with good ideas.

If people can get beyond the [notion that] "oh, it's the military" or [that] it's a political thing, and realize that it's a job, it's another place to work, then I think they could find it to be very exciting, very challenging, and very interesting. $\boldsymbol{n}$ 